\title{
BALANCE CASH-FLOW MODELS FOR PUBLIC INSTITUTIONS - CLIENTS AND SUPPLIERS
}

\author{
Gabi Georgiana Dragu', \\ Alina Puțan ${ }^{2}$ \\ Aitai Marian ${ }^{3}$
}

\begin{abstract}
According to position document no.11 "Economic and Monetary Union", Romania has committed to report after the European System of Accounts ESA 95. The classification of public institutions is necessary to circumscibe the Public Administrations'area (S.13), its division into subsectors and also to define the modalities of their financial statements' aggregation. The exploratory study and empirical observation were employed for this research. The exploratory study was used to enframe the issue into the general context. The data was collected by means of empirical experiment. The research aimed at assessing the practical utility of the model proposed in contributing to enhance correctness, premptitude and quality in delivering accounting information to its users.
\end{abstract}

Key words: European System of Accounts ESA 95, subsector, receivables, financial statements,

JEL codes: M41

\section{General background}

The need for relevant, objective information emanates from the entity's relation with the field of activity and requires an adequate offer. The accounting information delivered systematically by the practitioners of economical entities should be subservient for all the users of accounting products. The market of this information represents the intersection of this type of information demand and supply. The informational demand represents not only the informational necessities of various users, but also the pressures they make upon the information generator system. The informational supply represents not only the information obtained within the accounting informational system available for various users, but also their delivery means and forms.

In comparison to other informational sources, the accounting information is highly credible. This credibility is attained by the auditors who are responsible for the authentification of synthesis documents presented to the users by the managers.

\section{Romanian background}

The Accounting Law stipulates that all legal persons must employ double-entry accounting whereas the categories of individuals that may employ single-entry accounting are established by Order of the Ministry of Public Finances. The credit regulator is responsible for the organization and administration of the accounting department within public institutions.

Public institutions usually organize and administrate separate units that are led by the accounting manager, chief accountant or any other person authorized to carry out this job. These individuals must possess a University Degree in Economical Studies and are responsible for the organization and administration of the accounting department according to the law together with the subordinate personnel. The public institutions whose accounting department is not organized into separate units or whose personnel does not posess an adequate individual labor contract may sign, according to the law, a contract of services delivery for the administration and elaboration of the

\footnotetext{
${ }^{1}$ PhD Candidate, „1 Decembrie 1918” University of Alba Iulia; georgiana.dragu@yahoo.com

${ }^{2}$ PhD Student, „1 Decembrie 1918” University of Alba Iulia; putan.alina@yahoo.com

${ }^{3} \mathrm{PhD}$ candidate, University „Valahia” of Târgovişte; aitaimaf@yahoo.com
} 
trimestrial and annual financial statements with comercial audit firms or certified public accountants. According to the law, both categories must certify their affilliation to an active professional organization. The contracts must abide the legislation in effect regarding the regulations of the assets and services public acquisition.

In the case of Romania, national accounting is attempted to be positioned between two accounting cultures - the traditional continental accounting and the anglo-saxon accounting. Due to the comunist indoctrination, customs and the many legislative changes, the Romanian accountant that works in the public system demonstrates an aversion to change and he still needs to be said what/ how/ when to act.

The International Accounting Standards (IAS/IFRS/IPSAS) bare a cultural knowledge difficult to assimilate, they are based on the professional reasoning (that was not taken into account during the centralized period) and principles according to which a single problem might have multiple solutions (a fact that leads to controversies when confronted with the control board that might have some other solution). However, no matter their form, the International Accounting Standards are permanently changing, are becoming more and more complex therefore the Romanian accountant must become an international one, holding to the principles and conditions of international accounting.

To converge means ,to tend toward an intersection point, a common conclusion or result”. (Ristea M., 2004). In the accounting domain, convergence is a relatively new term, introduced in 2001 by the International Accounting Standards Board in the context of defining the objectives. One of these objectives states the following: „To collaborate actively with the national standards” regulation boards in order to identify qualitative solutions so that national accounting standards achieve the convergence with the accounting standards established by IASB".(Pop A., 2004).

According to the Romanian explanatory dictionary the conformity is defined as "a relation between two resembling or identical entities, matching, congruence and identity. The accounting conformity is the process that determines the congruence between the presented regulations' content and the elaboration of financial statements, representing an attunement of the national regulations to the regulations presented by the regional and international accounting standardization boards".

We adhere to the following conclusion according to which „Convergence represents the integration on a national basis of IAS/IFRS/IPSAS principles and theoretical background, respectively embracing some of the accounting processes stipulated by the international standards whereas standardization within accounting domain designates the consistency among and attunement to the accounting standards of various states in the European level" (Alecu G., Bojianu O., 2009).

Regarding the economical account, in many European Union's states the financial account is referred to as accrual due to lack of data and is characterized by the registration of revenues and expenses' commitments, ratified as to integrate the financial dimension of economical values based on the management of the economical accrual. Using the single-entry strategy, the Romanian public institutions register the revenues and expenses automatically based on the economical accrual for the reference period.

The objectives of the accounting standardization include: (Feleagă N., 1996)

"... to ensure the settlement of accounting practices and therefore contribute to accounting enhancement";

"... to allow the accounting information users to make rational decisions based on the accounting information";

"... to act as a moderator among the various participants in the economical field, especially among accounting information suppliers and accounting auditors that certify the quality of information thus ensuring the social credibility of the accounting information";

"... to allow the consolidation of accounting information at society's groups level";

"... to allow the elaboration of national statistics". 


\section{The Romanian subsectors' reporting}

According to the position document no. 11 "Economical Monetary Union", Romania has committed to report after the European System of Accounts ESA 95.

The introduction of subsectors' reporting is based on the 2009 internal and external reporting requirements established by the enactment of the Order of the Ministry of Public Finances no. 629/2009 regarding the approval of the Methodological Norms for the elaboration and deposition of public institutions' financial statements and also on some 2009 monthly financial reports with subsequent modifications and addenda (Order of the Ministry of Public Finances no. 2290/2009, Order of the Ministry of Public Finances 2941/2009).

The accounting information user deals with two types of sector organization:

- once the public institutions' reports are distributed into subsectors each one is assigned the annex for the affiliation sector

Annex 40a "Public institutions' assets and debts statement from central administration".

Annex 40b "Public institutions' assets and debts statement from local administration".

Annex 40c "Public institutions' assets and debts statement from the social insurance domain (public assistance, social security, health insurance)".

- Subsectors' data reports are organized the following way:

Table no.1

\section{Subsectors' data reports}

\begin{tabular}{|c|c|c|c|}
\hline $\begin{array}{l}\text { Sectors and Subsectors according to } \\
\text { European System of Accounts (ESA 95) }\end{array}$ & User & $\begin{array}{l}\text { Annex } 40 \\
\text { designation }\end{array}$ & $\begin{array}{c}\text { ESA } 95 \\
\text { Code }\end{array}$ \\
\hline Non-financial companies & Economic agents & & S.11 \\
\hline Financial companies & & & S.12 \\
\hline Central Bank & Romanian National Bank & & S.121 \\
\hline Other monetary financial institutions & \begin{tabular}{|c|}
$\begin{array}{c}\text { Residential credit } \\
\text { institutions }\end{array}$ \\
\end{tabular} & & S.122 \\
\hline $\begin{array}{l}\text { Other financial interagents, excluding } \\
\text { insurance companies and retiring fund }\end{array}$ & Other residents & & S.123 \\
\hline Auxiliary financial agents & Other residents & & S.124 \\
\hline Insurance companies and retiring funds & Other residents & & S.125 \\
\hline Public administrations & & & S.13 \\
\hline Central administration & & & S.1311 \\
\hline Local administration & & & S.1313 \\
\hline Social security administrations & & & S.1314 \\
\hline Others & Non-residents & & S.2 \\
\hline European Union & Non-residents & & S.21 \\
\hline European Union Member States & Non-residents & & S.211 \\
\hline European Union Institutions & Non-residents & & S.212 \\
\hline Tertiary's and international organizations & Non-residents & & S.22 \\
\hline
\end{tabular}

Source: Order of the Ministry of Public Finances no. 629/2009 regarding the approval of the Methodological Norms for the elaboration and deposition of public institutions' financial statements and also on some 2009 monthly financial reports with subsequent modifications and addenda (Order of the Ministry of Public Finances no. 2290/2009, Order of the Ministry of Public Finances 2941/2009). 
The classification of public institutions is necessary in order to circumscribe the Public Administrations' area, its division into subsectors, but is also necessary for defining the modalities of the financial statements' aggregation.

The ESA 95 handbook devides the public administrations' sector into four sectors

- Central Administrations (S.1311)

- Intermediate Administrations (S 1312), do not exist within Romanian subsectors

- Local Administrations (S.1313)

- Social Insurance Funds (S.1314).

Analyzing the structure of S.13 sector is necessary for evaluating the classification of the institutions into the above mentioned subsectors and assessing the transactions made by/ within public administrations.

Circumscribing the public administrations' area is essential for the elaboration of the sector's and public administrations' consolidated reports according to the identified standards at european and international level.

It should be noticed the difference between public sector and public administrations resulting from the modalities of institutions' clasification. According to ESA 95, an institution is included into S.13 subsector based on its financing modalities and on its committment to the so called $50 \%$ criteria. Since this criteria is strictly statistical, the inclusion or exclusion of an institution into the public administrations' list is not entirely based on its economical and legal profile. In the case of Romania, the institutions are included into the public administrations' area based on two elements:

- financing modalities

- legal statute

\section{Practical illustration of standardized reportingof debts towards the suppliers}

In the following section the information regarding the reporting of debts towards suppliers is illustrated through analytical models

The presentation after a current synthetically balance sheet:

Table no. 2

\section{Suppliers synthetically balance sheet}

\begin{tabular}{|l|c|c|l|}
\hline 40 & & & SUPPLIERS AND SIMILAR ACCOUNTS \\
\hline & 401 & & Suppliers \\
\hline & 404 & & Suppliers of long-term assets \\
\hline & & 4041 & Suppliers of long-term assets due in less than 1 year \\
\hline & & 4042 & Suppliers of long-term assets due in over 1 year \\
\hline & 408 & & Suppliers - unreceived invoices \\
\hline & 409 & & Suppliers - debtors \\
\hline & & 4091 & $\begin{array}{l}\text { Suppliers - debtors due to purchase of assets such as } \\
\text { stocks }\end{array}$ \\
\hline & & 4092 & Suppliers - debtors due to services and job run \\
\hline
\end{tabular}

Source: Briciu, S., Dragu, G. G, Ivan, O. R., Liability to suppliers reporting standardization- quality growth factor of account information, Conference Proceedings "European Integration -New Challenges For The Romanian Economy", 6-th edition, Oradea, 2010

First of all, the subsectors' analyzing method was attempted in order to automatically transfer the balance sheet data into "Annex 40 (a, b, c) Public institutions' assets and debts statement", correlated with the information from "Annex 30 Residual payments" which was found out to be filled with errors. 
Table no.3

Correlation table of “Annex 40 (a, b, c) Public institutions' assets and debts statement”, and "Annex 30 Residual payments

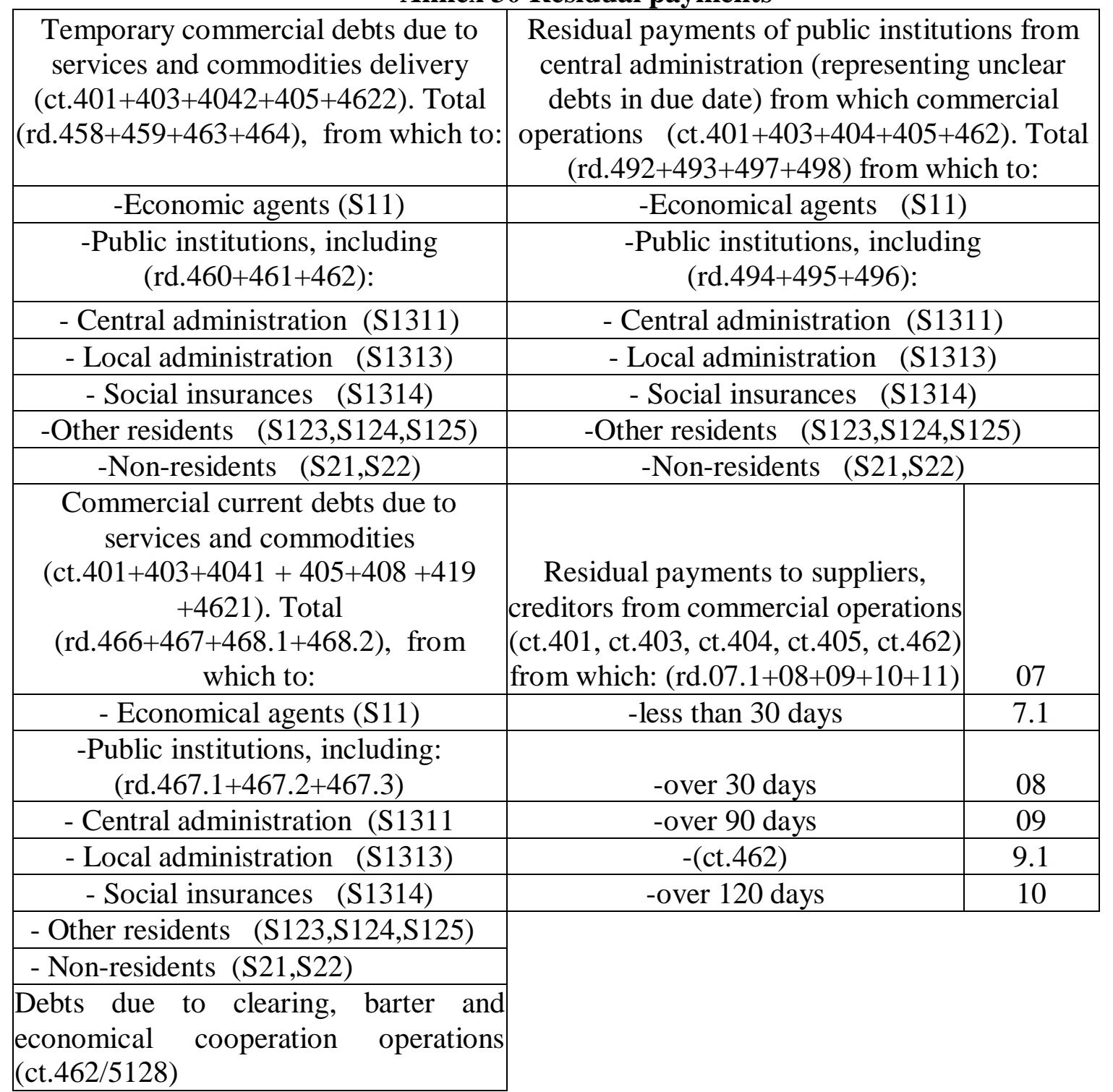

Source: Order of the Ministry of Public Finances no. 629/2009 regarding the approval of the Methodological Norms for the elaboration and deposition of public institutions' financial statements and also on some 2009 monthly financial reports with subsequent modifications and addenda (Order of the Ministry of Public Finances no. 2290/2009, Order of the Ministry of Public Finances 2941/2009).

Therefore, the following structure was attained in the first case:

The first degree syntetic account representing the suppliers was devided into current and temporary suppliers; these accounts were subsequently devided into subsectors' accounts with regard to their inclusion or exclusion from the clearing due date of the current period.

Suppliers

Suppliers - current debts

From which to the economical Subsector (according to each one's structure) from which In clearing due date from which.

With due date between 7 days, 8-30 days, 61-90 days, 91-180 days, with development in the analytical balance sheet on each reported unit.

Passed clearing due date from which. 
Debts that passed the legal clearing due between 7 days, 8-30 days, 61-90 days, 91-180 days, with development in the analytical balance sheet on each reported unit.

Suppliers - temporary debts

From which to the economical Subsector (according to each one's structure):

Table no.4

Model I for Suppliers syntetical balance sheet

\begin{tabular}{|c|c|c|}
\hline \multicolumn{3}{|c|}{ Suppliers (I) from which } \\
\hline \multicolumn{2}{|c|}{ Current suppliers from which } & $\begin{array}{l}\text { Temporary suppliers } \\
\text { from which }\end{array}$ \\
\hline \multicolumn{2}{|c|}{$\begin{array}{c}\text { Subsectors' suppliers - each sector follows the subsequent } \\
\text { structure }\end{array}$} & Subsectors' suppliers \\
\hline \multirow[t]{3}{*}{$\begin{array}{l}\text { within clearing due date } \\
7,30,60,90,180 \text { days }\end{array}$} & \multirow[t]{3}{*}{$\begin{array}{l}\text { within residuary due date } \\
><30,60,90,120,365 \text { days }\end{array}$} & $\begin{array}{l}\text { 1. }(\mathrm{S} 11)(\mathrm{S} 1311)(\mathrm{S} 1313) \\
\text { (S1314 }\end{array}$ \\
\hline & & 2. $(\mathrm{S} 123, \mathrm{~S} 124, \mathrm{~S} 125)$ \\
\hline & & 3. $(\mathrm{S} 21, \mathrm{~S} 22)$ \\
\hline
\end{tabular}

Source: Briciu, S., Dragu, G. G, Ivan, O. R., Liability to suppliers reporting standardization- quality growth factor of account information, Conference Proceedings "European Integration -New Challenges For The Romanian Economy", 6-th edition, Oradea, 2010

The limitations of this model consist of the following:

- the high error rate that might appear in the introduction of current clearing period data, due to the fact that the division is difficult in the case of the data concerning the subsequent period comparing to the residual payments whose reporting is based on the previous period

- the multitude of necessary operations at the end of the month in order to deliver a correct report that can also prove to be useful in the elaboration of the Cash-Flow (e.g. A 7 days clearing due date invoice would be delivered; if it had been received at the beginning of the month and it was not going to be payed until the end of the month, it would have been declared a residual payment; if it was remited at the end of the month, it would still have been classified as such).

The following structure was used within the second model:

Table no.5

Model II for Suppliers syntetical balance sheet

\begin{tabular}{|c|c|c|}
\hline \multicolumn{3}{|c|}{ Suppliers (II) from which } \\
\hline \multicolumn{2}{|c|}{ Current suppliers from which } & $\begin{array}{l}\text { Temporary suppliers } \\
\text { from which }\end{array}$ \\
\hline \multicolumn{2}{|c|}{ within clearing and residual payments due date from which } & Subsectors' suppliers \\
\hline \multirow[t]{3}{*}{$\begin{array}{l}\text { within clearing due date } \\
7,30,60,90,180 \text { days }\end{array}$} & \multirow[t]{3}{*}{$\begin{array}{l}\text { within residuary due date } \\
><30,60,90,120,365 \text { days }\end{array}$} & $\begin{array}{c}\text { 1. (S11) (S1311) (S1313) } \\
\text { (S1314 }\end{array}$ \\
\hline & & 2. $(\mathrm{S} 123, \mathrm{~S} 124, \mathrm{~S} 125)$ \\
\hline & & 3. $(\mathrm{S} 21, \mathrm{~S} 22)$ \\
\hline
\end{tabular}

Source: Briciu, S., Dragu, G. G, Ivan, O. R., Liability to suppliers reporting standardization- quality growth factor of account information, Conference Proceedings "European Integration -New Challenges For The Romanian Economy", 6-th edition, Oradea, 2010

The solution for current period payment due date distribution was given by the calendar month clearing due date formula. Therefore, the error rate was reduced in the case of classification according to clearing due dates so that invoices that had a 7, 30 or even 180 days due date could have matured within the same month. 
Problems appear within sanitary sector where, according to payment regulations, suppliers have an up to 180 days due date and starting with July these invoices must be included in the temporary debts even though they have a less than a year due date and could be payed until the end of year.

As a technological solution to avoid data introduction errors, starting with the calendar month that follows the passed due date month, the accounts that were due in that month do no longer show a balance account and the fields can no longer be completed (the balance account of the subsectors due in January must be zero starting with February either as a consequence of payment or a transfer into the 30 days residual payment category).

\section{Practical illustration of standardized reporting of clients}

In the following section the information regarding the reporting of clients is illustrated through analytical models

The presentation after a current syntetical balance sheet:

Table no.6

\section{Clients syntetical balance sheet}

\begin{tabular}{|l|l|l|l|l|l|l|}
\hline & 411 & & & & & Clients \\
\hline & & 4111 & & & & Customers $</=1$ year \\
\hline & & 4112 & & & & Clients $>/=1$ year \\
\hline & 418 & & & & & Customers invoices future \\
\hline & 419 & & & & & Clients -creditors \\
\hline
\end{tabular}

Source: Dragu, G. G., „Standardization of reporting receivables-quality enhancement agent in delivering accounting information „International Conference „S Sustainable development in condition of economic instability” second edition.

First of all, the subsectors' analyzing method was attempted in order to automatically transfer the balance sheet data into "Annex 40 ( $\mathrm{a}, \mathrm{b}, \mathrm{c})$ Public institutions' assets and debts statement", correlated with the information from "Annex 01 Balance" which was found out to be filled with errors.

Table no.7.1

\section{Commercial debt situation into "Annex 01 Balance"}

\begin{tabular}{|c|l|l|l|l|}
\hline 6. & $\begin{array}{l}\text { Trade receivables for the period following } \\
(\text { ct. } 4112+4118+4282+4612-4912-4962) \text { including: }\end{array}$ & 09 & 10 & \\
\hline $\begin{array}{l}\text { Trade receivables for the period following } \\
(\text { ct } 4112+4118+4612-4912-4962)\end{array}$ & 10 & \\
\hline
\end{tabular}

\begin{tabular}{|l|l|l|l|l|}
\hline $\begin{array}{l}\text { Trade receivables and advances (ct.232+234+409+ } \\
4111+4118+413+418+4611-4911-4961) \text { including: }\end{array}$ & 22 & & \\
\hline
\end{tabular}

Source: Order of the Ministry of Public Finances no. 629/2009 regarding the approval of the Methodological Norms for the elaboration and deposition of public institutions' financial statements and also on some 2009 monthly financial reports with subsequent modifications and addenda (Order of the Ministry of Public Finances no. 2290/2009, Order of the Ministry of Public Finances 2941/2009). 
Table no.7.2

\section{Commercial debt situation}

into "Annex 40 (a, b, c) Public institutions' assets and debts statement"

\begin{tabular}{|l|l|}
\hline $\begin{array}{l}\text { Trade receivables for the period following } \\
\text { (ct.4112+4118+4612-4912-4962). Sum (rd.293+294+295+299) } \\
\text { including: }\end{array}$ & 292 \\
\hline -Population, & 293 \\
\hline -Economic agents (S11), & 294 \\
\hline Public institutions, including: (rd.296+297+298) & 295 \\
\hline - Central administration (S1311) & 296 \\
\hline - Local administration (S1313) & 297 \\
\hline - Social insurances (S1314) & 298 \\
\hline - Non-residents (S21,S22) & 299 \\
\hline $\begin{array}{l}\text { Trade receivables for the current period } \\
\text { (ct.232+234+409+4111+4118+413+418+4611 -4911-4961). Sum } \\
\text { (rd.301+302+303+307) including: }\end{array}$ & 300 \\
\hline - Population & \\
\hline- Economic agents (S11), & 301 \\
\hline Public institutions, including: (rd.304+305+306) & 302 \\
\hline - Central administration (S1311) & 303 \\
\hline - Local administration (S1313) & 304 \\
\hline -- Social insurances (S1314) & 305 \\
\hline - Non-residents (S21,S22) & 306 \\
\hline $\begin{array}{l}\text { Trade receivables due to clearing, barter and economical cooperation } \\
\text { operations (ct.461/5128) }\end{array}$ & 307 \\
\hline
\end{tabular}

Source: Order of the Ministry of Public Finances no. 629/2009 regarding the approval of the Methodological Norms for the elaboration and deposition of public institutions' financial statements and also on some 2009 monthly financial reports with subsequent modifications and addenda (Order of the Ministry of Public Finances no. 2290/2009, Order of the Ministry of Public Finances 2941/2009).

Therefore, the following structure was attained in the first case:

The first degree synthetic account representing the clients was divided into current and clients suppliers; these accounts were subsequently divided into subsectors' accounts with regard to their inclusion or exclusion from the clearing due date of the current period.

Clients - current

From which to the economical Subsector (according to each one's structure) from which

In clearing due date from which

With due date between 7 days, 8-30 days, in the analytical balance sheet on each reported unit

Passed clients - current due date from which Clients that passed the legal clearing due between 7 days, 8-30 days, in the analytical balance sheet on each reported unit

Clients - temporary debts

From which to the economical Subsector (according to each one's structure). 
Table no.8

Model I for Clients syntetical balance sheet

\begin{tabular}{|c|c|c|}
\hline \multicolumn{3}{|c|}{ Clients (I) from which } \\
\hline \multicolumn{2}{|c|}{ Current clients from which } & $\begin{array}{l}\text { Future clients suppliers } \\
\text { from which }\end{array}$ \\
\hline \multicolumn{2}{|c|}{$\begin{array}{c}\text { Subsectors' clients - each sector follows the subsequent } \\
\text { structure }\end{array}$} & Subsectors' Clients \\
\hline \multirow[t]{3}{*}{$\begin{array}{l}\text { within clearing due date } \\
\text { 7, days }\end{array}$} & \multirow[t]{3}{*}{$\begin{array}{l}\text { within residuary due date } \\
\qquad>7<30 \text {, days }\end{array}$} & $\begin{array}{l}\text { 1. (S11) (S1311) (S1313) } \\
\text { (S1314 }\end{array}$ \\
\hline & & 2. $(\mathrm{S} 123, \mathrm{~S} 124, \mathrm{~S} 125)$ \\
\hline & & 3. $(\mathrm{S} 21, \mathrm{~S} 22)$ \\
\hline
\end{tabular}

Source: Dragu, G. G., „Standardization of reporting receivables-quality enhancement agent in delivering accounting information „International Conference „, Sustainable development in condition of economic instability” second edition.

The limitations of this model consist of the following:

- the high error rate that might appear in the introduction of current clearing period data, due to the fact that the division is difficult in the case of the data concerning the subsequent period - the multitude of necessary operations at the end of the month in order to deliver a correct report that can also prove to be useful in the elaboration of the Cash-Flow.

The following structure was used within the second model:

Table no.9

Model II for Clients syntetical balance sheet

\begin{tabular}{|c|c|c|}
\hline \multicolumn{3}{|c|}{ Clients (II) from which } \\
\hline \multicolumn{2}{|c|}{ Current Clients from which } & Future clients from which \\
\hline \multicolumn{2}{|c|}{$\begin{array}{c}\text { within clearing and residual collection } \\
\text { due date from which }\end{array}$} & Subsectors' Clients \\
\hline \multirow[t]{3}{*}{$\begin{array}{l}\text { within clearing due date } \\
\qquad 7,30 \text {, days }\end{array}$} & \multirow{3}{*}{$\begin{array}{l}\text { within residuary due date } \\
><30,60,90,120,365 \\
\text { days }\end{array}$} & $\begin{array}{c}\text { 1. (S11) (S1311) (S1313) } \\
\text { (S1314 }\end{array}$ \\
\hline & & 2. $(\mathrm{S} 123, \mathrm{~S} 124, \mathrm{~S} 125)$ \\
\hline & & 3. $(\mathrm{S} 21, \mathrm{~S} 22)$ \\
\hline $\begin{array}{r}\text { Each due date is es } \\
\text { The calendar month was } u\end{array}$ & $\begin{array}{l}\text { hed for each subsector; } \\
\text { the clearing due date }\end{array}$ & \\
\hline
\end{tabular}

Source: Dragu, G. G., „Standardization of reporting receivables-quality enhancement agent in delivering accounting information „International Conference „S Sustainable development in condition of economic instability” second edition.

The solution for current period collection due date distribution was given by the calendar month clearing due date formula..

As a technological solution to avoid data introduction errors, starting with the calendar month that follows the passed due date month, the accounts that were due in that month do no longer show a balance account and the fields can no longer be completed (the balance account of 
the subsectors due in January must be zero starting with February either as a consequence of collection or a transfer into the 30 days residual collection category).

\section{Conclusions}

The SWOT analysis of the attempt to standardize the reporting of debts to suppliers/trade receivables reveals the following:

Strengths

- provides a more clear image, contributes to the elaboration of Cash-Flow;

- the information concerning the debts are important regardless of their nature;

- contributes to a better assesment of the management, purchase and suppliers' due date accounts.

Weaknesses

- initially complex operations;

- insufficient human resources training and insufficient professional human resources;

Opportunities

- ensures credibility for the information provided on national level and especially on international level.

- reduces the risk of being sanctioned for exceeding the due date of statements' deposition or their inaccurate completion.

Threats

- insufficient human resources allotment can result in less relevant and credible information and delays in reporting the information to (inter)national boards, entailing sanctions.

\section{References}

1. Alecu G., Bojianu O., 2009, Convergences and Attunements of Accounting in Public Institutions, ASE Publishing, p.102.

2. Briciu, S., Dragu, G. G, Ivan, O. R., 2010, Liability to suppliers reporting standardizationquality growth factor of account information, Conference Proceedings "European Integration -New Challenges For The Romanian Economy", 6-th edition, Oradea, p.478483.

3. Dragu, G. G., 2010, Standardization of reporting receivables-quality enhancement agent in delivering accounting information, Proceedings of The International Conference "Sustainable development in condition of economic instability", June 18-19, 2010, Satu Mare, published in the electronic edition of Quality access to success Vol.11, No.113 Special, pag. 491.

4. Feleagă N., 1996, Taming the Accounting Jungle - Concept and Standardization in Accounting, Economica Publishing, Bucharest, p. 179.

5. Pop A., 2004, From Standardization to Convergence in Accounting, from Romanian Accountant Career Congress, Bucharest, 3 - 4 September, CECCAR Publishing, Bucharest.

6. Ristea M., 2004, Synchronic and Diachronic in International Accounting Attunement, from the Accountant Career Congress, Bucharest, 3 - 4 September 2004, CECCAR Publishing, Bucharest.

7. Order of the Ministry of Public Finances no. 629/2009 regarding the approval of the Methodological Norms for the elaboration and deposition of public institutions' financial statements and also on some 2009 monthly financial reports with subsequent modifications and addenda (Order of the Ministry of Public Finances no. 2290/2009, Order of the Ministry of Public Finances 2941/2009). 